\title{
ETHNICITY AND FINANCIAL EXCLUSION: HOW FRINGE BANKING HAS TAKEN HOLD IN ETHNIC AND IMMIGRANT NEIGHBORHOODS
}

\author{
Marie-Christine Pauwels \\ University of Paris Ouest Nanterre la Défense, France
}

In neighborhoods mostly peopled by low-income groups, ethnic minorities and immigrant communities, access to regular bank services is of ten difficult and fraught with many obstacles. When they need a shortterm loan, many of these customers will fall back on alternative financial services and visit either a payday lender, a pawnshop, a check-cashing outlet, a rent-to-own store or another similar kind of business.

This alternative or "fringe banking" sector has been developing and consolidating rapidly over the past two decades and its rate of growth is spectacular: in 2009 , there were almost 23,000 payday lenders nationwide against a mere 200 in the early nineties. Likewise, the number of pawnshops almost tripled between 1985 and 2006, climbing from 4,500 to almost 12,000 . In 2008, the Brookings Institution listed 48,000 of these non-bank establishments, versus slightly over 100,000 bank and credit union branches, and the number of online transactions is booming (estimates reckon that by $2016,60 \%$ of total payday loans will take place online against $35 \%$ in 2011$){ }^{1}$

One of the first to draw national attention to the size of this parallel economy was economist John Caskey in 1995 with his book Fringe Banking, which was followed ten years later by social policy analyst Howard Karger's Shortchanged: Life \& Debt in the Fringe Economy (2005). Since then, a whole body of literature on the topic has emerged, denouncing both the usurious and discriminatory practices of this sector but also the failure of regular banks to draw these customers back into their fold.

In 2009, the FDIC released its "National Survey of Unbanked and Underbanked ${ }^{2}$ Households", the first of its kind to analyze on a national scale those households who fall through the cracks of the mainstream

1 Daniel Brook, Harper's Magazine, April 2009, p.43; Brookings Institution, "Banking on Wealth: America's New Retail Banking Infrastructure and Its Wealth-Building Potential", January 2008; "Major Banks Aid in Payday Loans Banned by States", New York Times, February 232013.

2 The underbanked are people who have a checking or saving account but use non-bank money orders, check cashing services, payday loans, etc. at least once a year. 
banking system. ${ }^{3}$ Its findings, later confirmed in a follow-up study for 2011-2012 (which showed a worsening picture, $+0.6 \%$ in the proportion of unbanked households, and $+1.9 \%$ for the underbanked) were quite distressing (figure 1):

$>25.6 \%$ of U.S. households, about 30 million, are either unbanked ( 9 million) or underbanked (21 million), i.e. more than 60 million adults. These households have no or little relationship with a bank, savings institution, credit union, or any other mainstream financial service provider.

$>$ Minority populations are disproportionately represented since almost $54 \%$ of black households are either unbanked $(22 \%)$ or underbanked $(32 \%)$, while $43.3 \%$ of Hispanic households and $44.5 \%$ of American Indian/Alaskan households fall into this category. The figure for white households is of $18 \%$ only.

$>$ Households where Spanish is the only language spoken at home are also more likely to be unbanked $(35.6 \%)$, as are households where the householder is a foreign-born noncitizen (21.9\%)

$>$ In a number of areas, particularly in the South region, estimated minority unbanked and underbanked proportions substantially exceed the national estimate.

$>$ Last but not least, a substantial proportion of unbanked households were previously banked.

This survey confirmed previous findings, in particular the 2004 Working Paper from the Joint Center for Housing Studies at Harvard University which had already pointed out that the "unbanked" were overwhelmingly African-American and Hispanic, less educated, less affluent and younger than the population as a whole. ${ }^{4}$

Taking a look at the reasons given by these households for being unbanked or underbanked is very instructive:

3 FDIC National Survey of Unbanked and Underbanked Households, December 2009, http://www.fdic.gov/householdsurvey/full_report.pdf; see also the 2011 survey, http://www. fdic.gov/householdsurvey/2012_unbankedreport.pdf; and Howard Karger, "America's Growing Fringe Economy", Dollars \& Sense November/December 2006; Howard Karger, "The Modern Fringe Economy", The Social Policy Journal, vol. 3(1) 2004; and The Unbanked, fact sheet, University of Minnesota, 2006.

4 Christopher Barry, "To Bank or Not to Bank? A Survey of Low-Income Households", Joint Center for Housing Studies Working Paper Series, BABC 04-3. February 2004. 


\section{Figure 1. Comparison of Unbanked and Underbanked Households By RaCe AND ETHNicity}

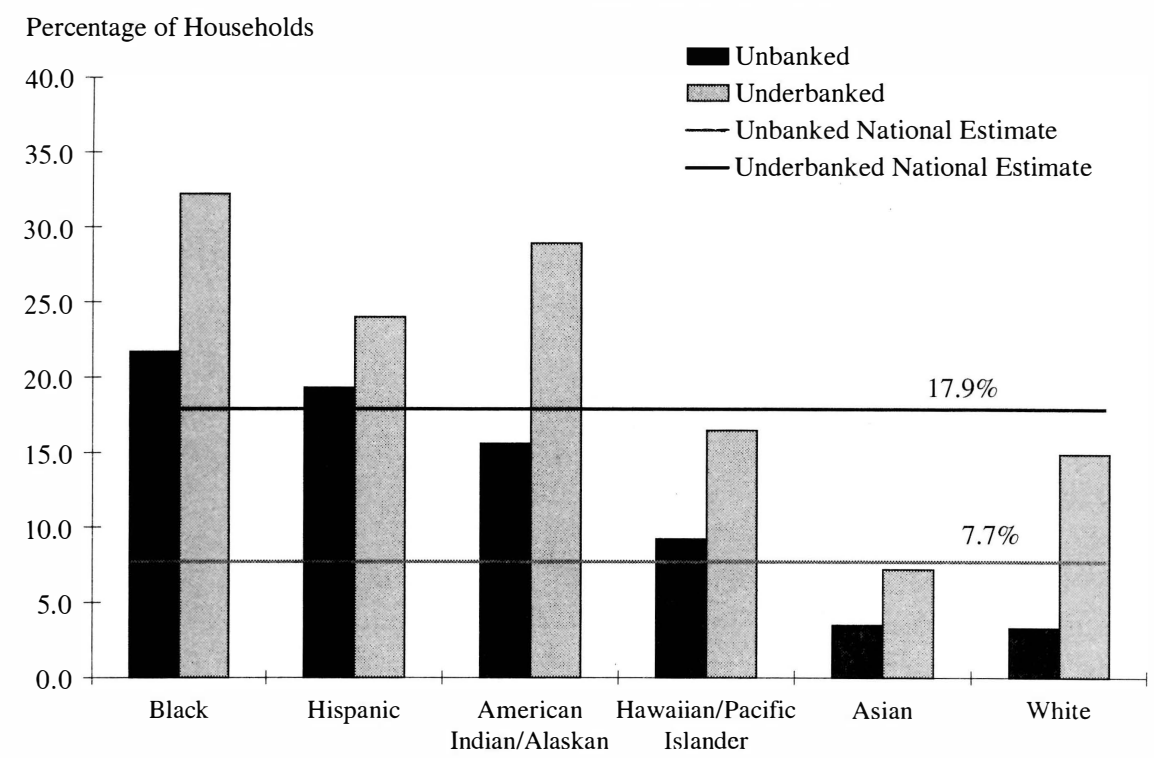

$>37 \%$ say they don't have enough money to need an account

$>18 \%$ don't write enough checks

$>12 \%$ complain the minimum balance requirement is too high

$>12 \%$ do not need or want an account/ did not see value of an account

$>9 \%$ say banks do not feel comfortable or welcoming

$>6.9 \%$ complain of language barriers

$>6.3 \%$ do not trust banks

$>5.5 \%$ have a legal status problem, or are unable to provide required residency documentation

Most of these factors reveal a deep disconnect with mainstream banks, and speak of a profound distrust toward businesses perceived as essentially catering to well-off and savvy customers. The unbanked overwhelmingly consider banks as hostile environments, ill-adapted to their needs and untrustworthy. In a 2004 Homeownership Alliance study of barriers to banking for Latin Americans, U.S. banks were called insecure, unsafe, unforgiving, unwelcoming, inflexible, and intimidating environments with language barriers. The same study suggested that more Hispanics would open bank accounts if the matricula consular card was more easily accepted for identification, if banks were flexible in mini- 
mum balance expectations, and if remittance rates were reasonably priced.

There is a great deal of self-censorship also: many unbanked people have simply integrated the notion that they don't need or deserve a bank account, let alone a credit which they fear will be rejected anyway. Other research on perceptions of creditworthiness reveals that African Americans in particular tend to be overly pessimistic about their credit scores, and are convinced they needn't bother ask a prime lender for a loan, because it will almost certainly be denied.

The alternative, then, is to turn to alternative financial services, aka fringe banking. Over $60 \%$ of unbanked households regularly visit a payday outlet, a check-cashing store, a pawnshop, and other similar businesses when they need to borrow small amounts of money and get cash fast. And what appears very clearly is that these fringe businesses have developed proactive, deliberate strategies of expansion toward ethnic and immigrant communities. There is indeed a disproportionate number of these outlets in relation to regular bank agencies in areas with large concentrations of minority and immigrant communities. ${ }^{5}$

In 2005, 2008 and 2009, the Center for Responsible Lending carried out three studies on payday lender locations in several states - North Carolina, Arizona, Texas and California. All three reached the same conclusions: minority neighborhoods (defined by the census tracts, i.e. areas comprising between 2,500 and 8,000 people), especially those with large African American, Latino, or Native American populations, were found to have three to eight times as many payday lending stores per capita as white neighborhoods (table 1). In California, while African Americans, Latinos, and Native Americans make up about a third (35\%) of the adult population, they represent $56 \%$ of all payday borrowers. In Texas, Blacks and Hispanics represent $40 \%$ of the adult population, yet $77 \%$ of all payday borrowers. ${ }^{6}$ It is undeniable that race and ethnicity were dominant factors in the decision of these fringe banks to settle in these neighborhoods.

One interesting finding is that even when both mainstream banks and fringe banking outlets co-exist in the same neighborhoods - which means these customers therefore have a choice - the unbanked/underbanked of ten deliberately choose the fringe banking outlets over the

5 Mark L. Burkey and Scott P. Simkins, "Factors Affecting the Location of Payday Lending and Traditional Banking Services in North Carolina" Review of Regional Studies, vol. 34 no. 2, Fall 2004, p.191-205; Assaf Oron, "Easy Prey: Evidence for Race and Military Related Targeting in the Distribution of Payday Loan Branches in Washington State", Department of Statistics, University of Washington, March 2006.

6 Wealth-Stripping Payday Loans Trouble Communities of Color, Center for Responsible Lending October 2, 2008. 


\section{TABLE 1}

COMMUNITIES OF COLOR MAKE UP HIGHER PROPERTIONS OF BORROWERS IN CALIFORNIA AND TEXAS

\begin{tabular}{|l|c|c|c|c|}
\hline & \multicolumn{2}{|c|}{ California } & \multicolumn{2}{c|}{ Texas } \\
\hline & $\begin{array}{c}\% \text { of total } \\
\text { payday } \\
\text { borrowers }\end{array}$ & $\begin{array}{c}\% \text { of total } \\
\text { adult } \\
\text { population }\end{array}$ & $\begin{array}{c}\% \text { of total } \\
\text { payday } \\
\text { borrowers }\end{array}$ & $\begin{array}{c}\% \text { of total } \\
\text { adult } \\
\text { population }\end{array}$ \\
\hline African American & $18 \%$ & $6 \%$ & $43 \%$ & $11 \%$ \\
\hline Latino & $36 \%$ & $28 \%$ & $34 \%$ & $29 \%$ \\
\hline Native American & $2 \%$ & $<1 \%$ & \multicolumn{2}{c|}{ Not available } \\
\hline
\end{tabular}

regular mainstream banks. ${ }^{7}$ Why is that so? Four main reasons can be identified:

$>$ Speedy and convenient transactions. Fringe outlets often act as one-stop shopping centers which offer all sorts of commercial services unavailable at the local bank. At a check-cashing outlet for instance, aside from cashing checks, one can also pay utility bills, transfer money for remittances ${ }^{8}$, place money orders, buy prepaid long distance calling cards, cell phones and beepers, send and receive a fax, xerox documents, buy postage stamps, envelopes, lottery tickets or even keep a mailbox.

$>$ Easy-to-get loans. To get a payday loan, almost anyone with a checking account and source of income gets approved, even with a poor FICO score (under 650); lenders usually do not conduct credit checks. The only paperwork required is a form asking con-

7 John Caskey, "Bank Representation in Low-Income and Minority Urban Communities", Urban Affairs Review, vol.29, 1994, p.617. The author who studied this pattern from 1970 to 1989 in five different cities (Atlanta, Denver, New York, San Jose, Washington D.C.) reports that in all five cities, areas with a dominant African-American or Hispanic population are substantially less likely to have a local bank compared to other communities but contends that this underrepresentation does not necessarily mean banks deliberately avoid minority areas. Low housing value/ lack of business activity can explain it; see also the National Community Reinvestment Coalition, "Are Banks on the Map? An Analysis of Bank Branch Location in Working Class and Minority Neighborhoods", 2007; and "Predatory Profiling: The Role of Race and Ethnicity in the Location of Payday Lenders in California", Center for Responsible Lending, March 26, 2009.

8 A large portion of these transactions does not occur through formal financial institutions. Rather than relying on traditional banks, many immigrants in the United States turn to smaller banks and credit unions, private money-transfer services and personal networks to send money to friends and relatives in their native country. 70-80\% percent of immigrants use wire transfer agencies such as Western Union and Moneygram to send money to friends and relatives in their home country. 
tact information about the customer, his/her spouse, landlord or mortgage holder, and three acquaintances. Applicants fill out the form, show proof of employment or another source of income such as Social Security, give their bank account number, and write a postdated check, dated to their next payday, for the loan amount plus the fee. It takes half an hour against several days at the bank. It is a form of fastfood banking.

$>$ Simplicity: pricing for these short-term loans is deceptively simple. For a payday loan, a fixed interest rate of around $\$ 15$ to $\$ 20$ is charged for each $\$ 100$ amount borrowed for a two-week loan, and there are no additional charges if the loan is paid back on time. It's easy to understand and the cash is available on the spot.

$>$ Personalized attention, friendly clerks and respect of sales personnel, trained to make these customers feel welcome and who are taught to empathize, the "we understand what you're going through" approach. Fringe banking sells itself as credit with a human face, contrary to the dehumanizing banks.

Many of the reasons people use these services are not linked to cost. The fringe banking system exists because it addresses a real need, which banks fail to do. These businesses pitch themselves as helping communities in need, and performing a necessary service which no other business cares to offer. In a sense, they are right. They have managed to gain the trust of these customers who choose to visit them, even though it may not be in their best interest.

No wonder retail giants are stepping on the bandwagon: Wal-Mart, which already had 1,800 "MoneyCenters" inside its U.S. stores, where shoppers can cash checks, transfer money, buy the WalMart prepaid debit card (the MoneyCard) for only $\$ 3$ (and no overdraft fees) added 500 more in 2010.

Meanwhile, the real cost of these credit products is astronomical. Asking for a $\$ 300$ payday loan for example, which comes with a $15 \%$ to $20 \%$ interest rate for a two-week period means writing a check for $\$ 360$, which amounts to annualized interest rates (APR or annual percentage rate) of over 400 percent. Because these loans are short-term, involve small amounts and are simple to get, most borrowers fail to appreciate how expensive they really are. They don't understand the difference between a percentage rate applied on a two-week loan and the percentage rate calculated over an entire year. The payday lending industry is a 
predatory industry that takes advantage of this assymetric information between borrowers and lenders. Even more disheartening, those who do know they are getting ripped off feel they have no other solution. What matters to people who live paycheck to paycheck is how much they are going to be paying weekly and whether they can afford it. Long-term strategies are not even an option, and fringe banking thrives on this sense of urgency.

The perversity of the system is that, unlike what the business wants us to believe, this service is not designed to help someone in trouble get an emergency one-time fix; instead, it is designed to keep the borrowers in a cycle of permanent debt. Research has shown that after the twoweek period, most borrowers are unable to pay back their initial loan, but instead roll it over into a new one, then a third, all the while paying the outlandish $\$ 15$ or $\$ 20$ finance fees each time. Only $25 \%$ of borrowers eventually manage to pay off. Meanwhile the average customer takes about ten payday loans a year.

The loan is structured as a trap. Some customers, to save face, take out a loan from another payday lender to pay the first and end up with multiple lenders to keep track of. The Center for Responsible Lending has found that 90 percent of business is generated by borrowers with five or more loans a year and over 60 percent of business is generated by borrowers with 12 or more loans a year. ${ }^{9}$ Payday loan losses are about $6 \%$ or less. A customer who pays off a loan or purchases a good or service outright is much less profitable than customers who keep returning for another loan. Most of the profit in the fringe economy lies with keeping customers caught in an expensive web of debt. Clearly, those who use these services have evolved from occasional users to chronic borrowers and payday lending has become a form of twentyfirst century sharecropping. ${ }^{10}$

The other most popular fringe banking services are offered by pawnshops, car title loans, tax refund anticipation loans and rent-to-own stores. Pawnshops offer small, short-term loans with personal items, such as jewelry or large electronics, as collateral. The average pawnshop loan is about $\$ 75$ but can go as low as $\$ 15$. Interests are as high as 25 percent. Loopholes in state usury laws of ten allow them to rollover fees and finance charges also. The pawnshop collects the item if the borrower defaults on his payment. Pawnshops are less popular in comparison to

9 Wealth-Stripping Payday Loans Trouble Communities of Color, op.cit.

10 Payday lending is legal and regulated in 37 states. It was first authorized in 1996. In Georgia, North Carolina and 11 other states, it is either illegal or not feasible, given state law. Yet most of the regulatory efforts to police the sector have been ineffective so far: customers simply take back-to-back transactions when renewing the loan immediately is not allowed, and cooling-off periods to prevent rollovers are totally artificial as borrowers still take a new loan after a few days. 
payday lenders today because there is no need to leave personal possessions as collateral. Yet, payday loans can inflict potentially greater damage on borrowers. For instance, if a consumer abandons a pawned item, the lender retains the collateral and the borrower is not pursued. No report is filed with a collection agency nor is the borrower's credit history blemished. On the other hand, defaulting on a payday loan will taint the creditworthiness of the borrower, if not destroy it. These businesses have evolved into a multi-service industry; some also provide payday loans and other financial services. There were 4,500 pawnshops in the United States in 1985; in 2006 they had grown to almost 12,000, including outlets owned by five publicly traded chains. ${ }^{11}$

Car title loans are a variation of the typical pawn loan. A person who owns his/her car can take out a small loan, usually around $25 \%$ of the value of the car, using the car title as collateral. Repayment is usually made over a number of monthly payments, and interest rates are typically up to $20 \%$ per month. Car title loan contracts are set up so the lender can collect the car if the borrower defaults, even on only one payment. Unlike pawnshop transactions, the consumer does not forego the use of his property during the course of the loan, even though the vehicle is technically owned by the lender until the loan is repaid.

Tax refund anticipation loans (RALs) are short-term loans secured by an expected tax refund. RALs are also expensive and similar to other forms of fringe credit with an APR which can range from 67 to over $700 \%$ percent. Of the several million taxpayers who receive RALs, almost half get them through H\&R Block, the largest tax preparer in the nation (Jackson Hewitt is second). RALs are common in low-income neighborhoods, due to tax refunds under the federal EITC program. Since taxpayers must file a federal income tax form to receive an EITC refund, many use tax preparers and are thus able to get their hands on their EITC refund more quickly, unaware that they are in fact getting a predatory loan, basically borrowing their own money and paying high interest rates for it.

Finally, Rent-to-own Stores are outlets that offer credit to consumers to purchase large appliances, electronics, and furniture. Consumers agree to a series of weekly or monthly payments, but usually end up paying back two to three times the retail amount of the item. However, they don't own the product in full until the final payment, and if they default on their payments, the product must be returned and the consumer is not compensated. Customers are thus hit with excessive interest rates, exceedingly high fees, or exorbitant prices for services or goods they end up paying two to three times as much as if they'd paid the retail 
price upfront. "According to the Consumer Federation of America, customers with RTO contracts pay between $\$ 1,000$ and $\$ 2,400$ for a TV, stereo, or other major appliance worth as little as $\$ 200$ used, and seldom more than $\$ 600$ new." 12

\section{CONCLUSION}

Whether one patronizes a payday lender, a pawnshop, a check-cashing outlet, or get a tax refund loan from a tax preparer like H\&R Block or Jackson Hewitt, which is basically a way of borrowing one's own money and pay high interest rates for it, all these examples point to a similar business model: taking advantage of vulnerable, misinformed, sometimes helpless customers, many of whom are ethnic minority customers, and offering them predatory credit services, while pretending to be performing a form of community service and acting as much needed substitutes for an inadequate and faulty banking system. The ultimate irony is that for many of these fringe banking customers, these short-term loans may in fact be the cheapest option available, compared with the sometimes prohibitive overdraft protection fees offered by regular banks, or the astronomical credit card fees.

In spite of existing legislation such as the Community Reinvestment Act of 1977 which mandated that federally insured banks meet the credit needs of their entire communities, including low-income people, and thus prevent the redlining process, segregation in the credit market, far from disappearing, has intensified, because the American banking industry has become polarized between regular banks in the top tier of the system who cater to the wealthier and less risky customers, and a flourishing market of second and third tier outlets which practice usury lending and take advantage of the more vulnerable. We could describe what is taking place today as a form of redlining in reverse, one that still discriminates against poor communities, only this time not by excluding them from credit, but by offering instead quick, easy, convenient access to plenty of credit products which turn out to be scandalously expensive and which ensnare them into a debt trap. This is not the way ethnic minorities are going to build up equity. These communities don't have access to the safe, mainstream and asset-building kind of credit, and are steered toward the exploitative options instead. In the words of Howard Karger: "one set of rules for the rich, another set of nonrules for the poor". ${ }^{13}$ Meanwhile, the racial gap in access to fair credit continues unabated.

12 Howard Karger, Shortchanged, Life and Debt in the Fringe Economy, Berrett-Koehler Publishers, 2005, p.96.

13 id, p.xi. 